スクリーン時間ならびに勉強時間と体力の関連

一震贸後における東北太平洋側地域の高校 2 年生を対象とした横断研究一

\author{
中條 雅彦 ${ }^{1}$, 門間 陽樹 ${ }^{2}$, 黄 聡 ${ }^{2}$ ，永富 良一1,2
}

\title{
Association between screen viewing time and study time of physical fitness: A cross-sectional study among second-year high school students of the Pacific side in the Tohoku region after The Great East Japan Earthquake disaster
}

\author{
Masahiko Chujo ${ }^{1}$, Haruki Momma ${ }^{2}$, Cong Huang ${ }^{2}$ and Ryoichi Nagatomi ${ }^{1,2}$ \\ ${ }^{1}$ 東北大学大学院医学系研究科運動学分野， ₹980-8575 宮城県仙台市青葉区星陵町 2-1 (Department of Medicine and Sci- \\ ence in Sports and Exercise, Graduate School of Medicine, Tohoku University, 2-1 Seiryo-machi, Aoba-ku, Sendai, Mi- \\ yagi 980-8575, Japan) \\ 2 東北大学大学院医工学研究科健康維持増進医工学分野, =980-8575 宮城県仙台市青葉区星陵町 2-1 (Division of Biomedi- \\ cal Engineering for Health and Welfare, Graduate School of Biomedical Engineering, Tohoku University, 2-1 Seiryo- \\ machi, Aoba-ku, Sendai, Miyagi 980-8575, Japan)
}

Received: January 27, 2015 / Accepted: April 22, 2015

\begin{abstract}
The purpose of this study was to examine the association of screen viewing time (SVT) and study time (ST) with physical fitness among second-year high school students. This cross-sectional study was carried out including 678 (boys: $\mathrm{n}=322$ ) students enrolled from 2011 to 2013. Physical fitness measurements included muscular fitness, explosive power and endurance performance. Muscular fitness and explosive power were evaluated by grip strength and standing broad jump test, respectively. Endurance performance was evaluated by endurance running speed of 1500 meters (in boys) or 1000 meters (in girls) running. SVT, ST and other lifestyle behaviors were obtained by a self-reported questionnaire. Analysis of covariance was used to examine the association of SVT and ST with grip strength, standing broad jump distance and endurance running speed. After adjustment for potential confounders, longer SVT was associated with poorer endurance running speed in both boys and girls, ( $p$ for trend $<0.01$ ). Longer SVT was also associated with lower standing broad jump distance in boys ( $\mathrm{p}$ for trend $=0.007$ ) and grip strength in girls ( $\mathrm{p}$ for trend $=0.005$ ). In boys, longer ST was also associated with lower grip strength after adjustment for potential confounders ( $p$ for trend $=0.007$ ). In conclusion, these results suggest that differences between SVT and ST may have different effects on physical fitness data 3-year after the earthquake disaster. Further studies are necessary to confirm the findings of this study.
\end{abstract}

Jpn J Phys Fitness Sports Med, 64(3): 323-332 (2015)

Keywords : screen viewing time, study time, physical fitness, high school students, cross-sectional study

\section{緒言}

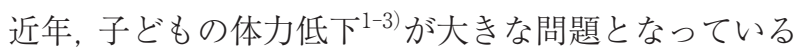
ことはよく知られている。毎年, 文部科学省が実施して いる新体力テストの報告によると，平成 25 年の高校生 の持久走（男子 $1500 \mathrm{~m}$, 女子 $1000 \mathrm{~m}$ ) と握力は, 昭和 60 年頃と比較すると $1500 \mathrm{~m}$ で約 4\%, $1000 \mathrm{~m}$ で約 $6 \%$, 握力で男女いずれも約 $6 \%$, 各々の種目で低い值を示し ている ${ }^{4)}$. 高校生の体力は成人期以降の生活習慣病の発
症と関連すること ${ }^{5,6)}$, さらに青年期の体力が高ければ成 人期以降の体力も高い值を示すこと年を考慮すると，青 年期の体力を高いレベルに向上し，それを維持すること が将来の健康にとって重要であるといえる。

子どもの体力低下の原因として, 学外の学習活動や室 内での遊び時間の増加，いわゆる，学習時間や座位行動 の増加が影響力の強い原因の一つとして挙げられてい る1,3). 実際に, 青年期を対象にした先行研究において, テレビ（TV）視聴時間は心肺体力と負の関連を示し ${ }^{8)}$, 
また，TV視聴時間と筋力についても負の関連が認めら れている ${ }^{9)}$. 生活環境の変化や価值観の多様化により, 特に最近の高校生は, 通学や部活動, 放課後の行動, 勉 強に費やす時間は様々であり, 座位行動や勉強時間など に関わる時間は, 個々人の生活様式に強く影響を受ける と考えられる．学内での生活は基本的に一様であること を考えると, 放課後の過ごし方が体力に強い影響を与え ている可能性が高い. 日本の高校生は, 放課後に勉強お よびTVの視聴, パソコン, TVゲームに費やす時間（ス クリーン時間）はそれぞれ約 1 時間 ${ }^{10)}$ および約 2 時間11) と報告されており, 先行研究で注目されているスクリー ン時間に加えて, 学外での勉強時間が体力に与える影響 も無視することはできない. しかしながら, その一方で, 学業成績と体力テストの成績は正の関連を示し ${ }^{12)}$, 勉強 時間と学業成績は正の関連を示すことから ${ }^{13)}$, 学外での 勉強時間と体力は正の関連を示す可能性も考えられる。 しかし, 学外での勉強時間が体力に対し, どのような影 響を与えるかについて検討した研究は, 現在のところ報 告されていない.

そこで, 本研究は, 日本の高校生を対象に, 学外のス クリーン時間および勉強時間と体力との関連について検 討することを目的とした，本研究においては，スクリー ン時間および勉強時間が長ければ, 体力指標は低い值を 示すと仮説を立て検証を行った。

\section{方 法}

対象者 対象者は, 2011年〜2013年の間, 東北太平洋側 地域の中都市に位置し, 2011年 3 月に東日本大震災で被 災した $\mathrm{N}$ 高校に在籍した 2 年生 857 人である。このうち
身長，体重の欠損值のある者 140 人，体力データの欠損 值のある者 9 人, 生活習慣のデータの欠損值のある者 30 人をそれぞれ除外し, 最終的な分析対象者は, 678 人（男 子 322 人，女子 356 人）とした（Fig. 1).

体力測定は，2011年～2013 年の各年 6 月上旬に市営 陸上競技場で当該校の保健体育科教員が実施した。たた し，2011年は東日本大震災の影響により，同年 9 月上旬 に校庭と同校体育館で実施した。 1 年生は受験後のため 体力を正確に把握しにくく，また，3 年生はこの時期進 路実現に向けた準備に取り掛かることから, 対象を 2 年 生に限定した。測定は, 本研究を行うにあたり, 事前に 生徒とその保護者に調査の内容を説明したうえで, 書面 で同意を得た。本研究は, 東北大学大学院医学系研究 科倫理委員会の承認を得て実施した（承認番号 2014- 1549).

体力評価 体力評価を行うため, 新体力テスト実施要 項 ${ }^{14)}$ に基づき, 新体力テストを行った。本研究において は, 新体力テストの項目のうち国際的な子供期・青年期 の健康関連体力テストであるThe ALPHA (Assessing Levels of Physical Activity) Fitness tests battery ${ }^{15)}$ で 妥当性・信頼性・安全性が認められている握力, 立幅 跳, $20 \mathrm{~m}$ シャトルラン (SR) を体力指標として採用した. ALPHA と新体力テストの評価の解釈, 実施方法は同じ である。さらに心肺体力の評価は, 先行研究16)で採用さ れ，一度に多くの人数を少ない用具（たとえばストッ プウォッチ）で測定可能な ${ }^{17)}$ 持久走（男子 $1500 \mathrm{~m}$, 女子 $1000 \mathrm{~m}$ ）を本研究で採用した（ただし, 新体力テストは, $20 \mathrm{mSR}$ 持久走のどちらかを選択することとなってい

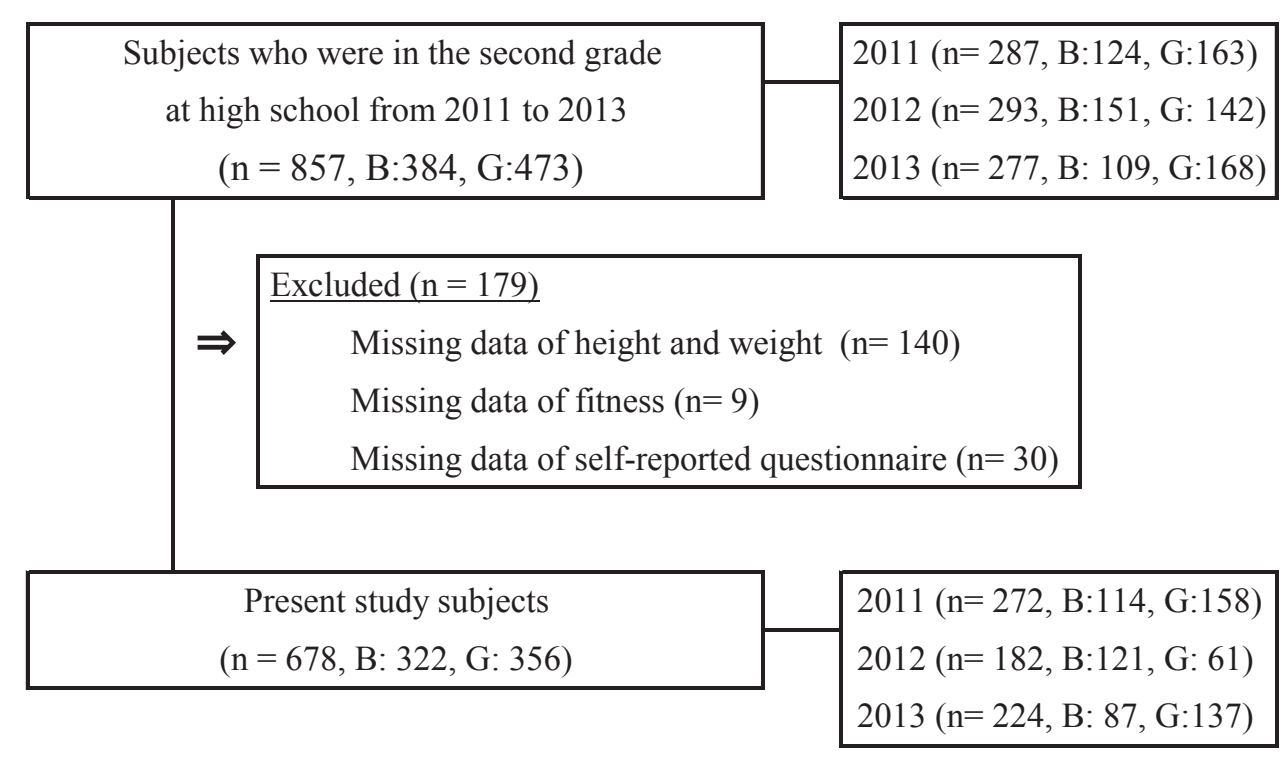

Fig. 1 Flowchart of subjects in this study. Boys: B, Girls: G 
る). 先行研究から全身持久力の評価に対して, 長距離 走 $(5 \mathrm{~km})$ と $20 \mathrm{mSR}$ には強い相関関係 $(\mathrm{r}=-0.96)$ があることが認められている18)。本研究においては，他 の体力指標との評価に方向性を一致させるため, 持久走 の測定タイムから走速度 $(\mathrm{m} / \mathrm{sec})$ を算出し, 走速度を 持久走の成績とした（すなわち, 走速度の速い方が持久 走の成績は良いこととなる).

\section{座位時間評価}

I スクリーン時間評価 本研究では, 先行研究 19,20$)$ か ら TV 視聴，TVゲームやパソコンに従事する時間をス クリーン時間と定義した。対象者は, 自記式アンケート にて,「一日の TV 視聴時間 (TVゲーム・パソコン含む) は?」という質問に, ( $1: 1$ 時間未満, $2: 1 \sim 2$ 時間, $3: 2 \sim 3$ 時間, $4: 3$ 時間以上) から選択し回答した. II 勉強時間評価 本研究では, 学校以外での一日の平 均勉強時間（塾も含む）を勉強時間と定義した。対象者 は, 自記式アンケートにて,「学校以外での一日の平均 勉強時間（塾も含む）は？」という質問に，（1：ほと んどしない, $2: 30$ 分くらい, $3: 1$ 時間くらい, 4: 2 時間以上）から選択し回答した。勉強時間に関しては $\lceil 4 ： 2$ 時間以上」の人数が少ないことから「3：1時 間くらい」と合わせ「1時間以上」とカテゴリー化した．

その他の評価 身長, 体重, 生活習慣に関する調査は自 記式アンケートを用いた。身長や体重の自己申告と実測 值との相関は高く, 妥当性は示されているが21,22), 女性は, 男性に比べ体重を過小評価し, 子供より若者にその傾向 が強いことが知られている22). Body Mass Index (BMI) は体重（kg）を身長（m）の二乗で除して算出した。「朝 食を毎日食べますか？」については，（1：毎日食べる, 2 ：時々欠かす， 3 ：まったく食べない）から選択して もらった， 2 と 3 を合わせ「欠食」にカテゴリー化した。 「一日の平均睡眠時間は? 」については, ( $1: 6$ 時間未満, $2: 6 \sim 8$ 時間未満, $3: 8$ 時間以上) から選択してもらっ た. 2 と 3 を合わせ「 6 時間以上」にカテゴリー化した。 「体育授業以外の運動・スポーツ活動は？」については, 先行研究 ${ }^{23}$ や新体力テス卜実施要項で用いている記録用 紙 $^{14)}$ の質問項目を採用し，(1：ほとんど毎日（週 3 日以 上), 2 : 時々（週 $1 \sim 2$ 日）, 3 : ときたま（月 $1 \sim 3$ 日), 4 ：しない）から選択してもらった。なお, 運動 頻度による質問紙の調査は，すでに信頼性㧍よび妥当性 が確認されている 各々と $20 \mathrm{mSR}$ の平均回数との相関に大きな差は見られ ず，評定一致率も $82 \%$ 94\% と，かなり高い值を示して いることから結果に対する類似性は高いといえる ${ }^{24)}$.「運 動・スポーツ」とは, 先行研究25) より課外活動時の運動・ スポーツ，および健康・体力維持向上を目的として行う
ウォーキングや体操を含むことが知られている， 1 と 2 を合わせ「週 $1 \sim 2$ 日以上」，3 3 と 4 を合わせ「月 1 3 日以下」に各々カテゴリー化した。運動部活動所属の 有無については，入部している場合には，その部活名の コード番号を選んでもらい,「運動部活動所属有り」と「運 動部活動所属なし」にカテゴリー化した。

統計解析 連続デー夕は平均土標準偏差で示し, カテゴ リーデータは割合（\%）で示した。スクリーン時間拉よ び勉強時間とその他の変数の関連を検討するため, 連続 デー夕に関しては一元配置分散分析とその線形性（傾向 性）の検定を行い，カテゴリーデータに関しては $\chi^{2}$ 検定 とその連関の検定を行った，スクリーン時間および勉強 時間と握力，立幅跳，持久走の走速度の関連を検討する ため, スクリーン時間, 勉強時間をそれぞれ独立変数, 握力, 立幅跳, 持久走の走速度をそれぞれ従属変数とし た共分散分析とその線形性の検定を行った. 補正項目は, 先行研究ならびに体力に影響を与える可能性がある変数 とし, $\mathrm{BMI}^{26)}$ ，朝食摂取習慣 ${ }^{27}$, 睡眠時間 ${ }^{28)}$, スクリーン 時間, 勉強時間, 体育授業以外の運動・スポーツ実施状 況 $^{29)}$, 運動部活動所属の有無 ${ }^{30)}$ 共変量として用いた。 ただし，スクリーン時間および勉強時間がそれぞれ独立 変数となっている場合は，それぞれ補正項目から除外し た．スクリーン時間と体力の関連に関しては，モデル 1 でBMI, 朝食摂取習慣, 睡眠時間, 勉強時間で調整し, モデル 2 でモデル 1 に体育授業以外の運動・スポーツ実 施状況，運動部活動所属の有無を加え調整した，勉強時 間と体力の関連に関しては, モデル 1 でBMI, 朝食摂取 習慣，睡眠時間，スクリーン時間で調整し，モデル 2 で モデル 1 に体育授業以外の運動・スポーツ実施状況, 運 動部活動所属の有無を加え調整した。一元配置分散分析 抢よび共分散分析の傾向性の検定には，一般線形モデル の対比による線形性の有意確率を採用し， $\chi^{2}$ 検定の傾 向性の検定には, 線型と線型による連関の有意確率を 採用した。分析は, SPSS software version 11.0 (SPSS Japan Inc., Tokyo, Japan）で行い, 危険率 5\%をもって 統計学的有意水準とした.

\section{結 果}

スクリーン時間と体力指標との関連 スクリーン時間に おける対象者特性をTable 1 に示す。男子に拀いて, ス クリーン時間が長くなるにつれ，運動部所属者の割合（傾 向性 $\mathrm{p}$ 值 $=0.022 ）$ は，低い值を示した。一方，朝食を欠 食する者の割合（傾向性 $\mathrm{p}$ 值 $=0.017 ）$ ，抒よび体育授業 以外の活動が月 1-3 日以下の者の割合（傾向性 $\mathrm{p}$ 值 $=$ 0.001）は，スクリーン時間が長くなるにつれ，高い值を 示した，女子においてはスクリーン時間が長くなるにつ れ, 勉強時間が 1 時間以上の者の割合（傾向性 $\mathrm{p}$ 值 $=$ 
0.024）は低い值を示した。一方，スクリーン時間が長く なるにつれ，体育授業以外の活動が月 $1-3$ 日以下の者 の割合（傾向性 $\mathrm{p}$ 值 =0.001）は高い值を示した，その他 の変数に関しては, スクリーン時間と有意な関連は認め られなかった。

スクリーン時間と握力, 立幅跳, 持久走の走速度との 関連をTable 2 に示す，男子に扔いて，スクリーン時間 が長くなるにつれ，立幅跳扔よび持久走の走速度は低い 值を示した，生活習慣を考慮したモデル 1 で調整後, 運 動状況を考慮したモデル 2 に拈いても, 立幅跳㧍よび 持久走の走速度に打いて有意な負の関連（傾向性 $\mathrm{p}$ 值 <0.01）が認められた，女子に扔いて，スクリーン時間が 長くなるにつれ，握力および持久走の走速度は低い值を 示した、モデル 1 およびモデル 2 に打いても, 握力およ び持久走の走速度に扔いて有意な負の関連（傾向性 $\mathrm{p}$ 值 <0.01）が認められた.

勉強時間と体力指標との関連勉強時間における対象 者特性をTable 3 に示す, 男子に打いては, 勉強時間 が長くなるにつれ，運動部所属者の割合（傾向性 $\mathrm{p}$ 值 <0.001）抢よび体育授業以外の活動が週 1-2 日以上の 者の割合（傾向性 $\mathrm{p}$ 值 $=0.020 ）$ は低い值を示した，女子 に扔いては，スクリーン時間 3 時間以上視聴する者の割 合は, 勉強時間が長くなるにつれ，低い值を示した（傾 向性 $\mathrm{p}$ 值 $=0.024)$. 一方, 朝食を毎日摂取する者の割合は, 勉強時間が長くなるにつれ，高い值を示した（傾向性 $\mathrm{p}$ 值 $=0.016)$. その他の変数に関しては, 勉強時間と有意 な関連は認められなかった。

勉強時間と握力, 立幅跳, 持久走の走速度の関連を Table 4 に示す. 補正前, モデル 1 で調整後, 男子におい ては，勉强時間が長くなるにつれ，握力および持久走の 走速度いずれも（傾向性 $\mathrm{p}$ 值 $<0.05 ）$ 有意な負の関連が 認められた。一方で，運動状況を考慮したモデル 2 にお いては, 握力では勉強時間と有意な負の関連が認められ た（傾向性 $\mathrm{p}$ 值 $=0.007 ）$ が, 持久走の走速度と勉強時間 の関連には有意性は認められなくなった（傾向性 $\mathrm{p}$ 值 $=$ 0.459). 女子に打いては, 補正前, モデル 1 抢よびモデ ル 2 に扔いても有意な負の関連を認めなかった。

\section{考察}

本研究は, 同一高校 2 年生に打ける 3 年間分の新体力 テストデータを用いてスクリーン時間ならびに勉強時間 と握力, 立幅跳抢よび持久走の走速度との関連について 横断的に検討した。 その結果, スクリーン時間について は，男子に扔いて立幅跳㧍よび持久走の走速度で有意な 負の関連を認め, 女子に扔いて握力㧍よび持久走の走速 度で有意な負の関連を認めた。また, 勉強時間について は, 男子に扔いて握力と有意な負の関連を認めた。一方
で，女子において勉強時間とすべての種目で有意な関連 を認めなかった. 従って, 高校生の学外での長いスクリー ン時間ならびに勉強時間は, 体力に対し, 好ましくない 影響を与える可能性がある。

まず，スクリーン時間と持久走の走速度の関連におい ては, Pateらは, 12歳から 19歳までのアメリカ人男女 3287 人を対象にトッレドミルを用い, 最大酸素摂取量 $\left(\dot{\mathrm{V}} \mathrm{O}_{2 \max }\right)$ と TV 視聴時間を横断的に評価し ${ }^{8)}$ ，男女いず れも心肺体力は, $\mathrm{TV}$ 視聴時間の長さと有意な負の関連 を認める報告をしている. Hardy $ら^{311}$ は, 11-15歳のオー ストラリア人 2750 人を対象にスクリーン時間と $20 \mathrm{mSR}$ の関連を検討した結果，女子に执いては，すべての年齢 で $20 \mathrm{mSR}$ とスクリーン時間は負の関連を認めている. しかし, 男子に扔いては, 約15歳で関連を認めなかっ たが, 約 11 歳㧍よび約 13 歳では，スクリーン時間と 20 $\mathrm{mSR}$ は負の関連を認めることを報告している，男子の 約 15 歳においてスクリーン時間と $20 \mathrm{mSR}$ に関連を認め なかった理由として, 身長の発育速度がピークになるこ と peak height velocity (PHV) が, $\dot{\mathrm{V}} \mathrm{O}_{2 \max }$ に正の影響を 及ぼし，スクリーン時間の負の影響を受ける以前の水準 まで $20 \mathrm{mSR}$ の成績を高めた可能性 ${ }^{31)}$ を指摘している. 日本人の PHV の平均年齢は女子で 11 歳頃（小学 5 年生 頃), 男子では 13 歳頃（中学 1 年生頃）であり ${ }^{32}$, $\mathrm{PHV}$ ではホルモンの活動が非常に活発であるため, 外部から の刺激で内的な成長それ自体の効果を上まわることはで きないこと㬏が報告されている。本研究の対象年齢は, 16 歳〜17歳であり, PHVの平均年齢を上回る. よって Hardyらが指摘した身長の発育に伴う成長因子を，完全 に除去できるとは言い切れないが，本研究の男子に执い ては, 先行研究が指摘したスクリーン時間が体力に与え る負の要素を上回るPHVの影響を受けた可能性は，低 いと言えるだろう. 先行研究8,31)で, スクリーン時間と心 肺体力は，打打上そ負の関連があり，本研究は，対象集 団が限定されるが，この関連を支持する結果を提示した といえる。心肺体力とスクリーン時間に負の関連を認め る理由としては, スクリーン時間が長くなること，つま り,横たわった状態や座った状態などが続くことで,ベッ トレストに近い安静状態になり，一回の心拍出量が低下 すること融が指摘されている. 心肺体力は, $\dot{\mathrm{V}} \mathrm{O}_{2 \max }(\mathrm{ml} /$ $\mathrm{kg} / \mathrm{min})$ で評価され，一回の心拍出量が低下することで 持久走の走速度が低くなる可能性が考えられる。本研究 では，スクリーン時間と男子の立幅跳抢よび女子の握力 で有意な負の関連を認めている。青年期を対象としたス クリーン時間と握力および立幅跳を評価した検討は, 今 までなされて扔らず，長いスクリーン時間が，男子にお いては立幅跳で，女子に打いては握力と有意な負の関連 を認める新しい知見を示すと思われる。青年期を対象と したスクリーン時間と体幹の等尺性の筋力との関連につ 


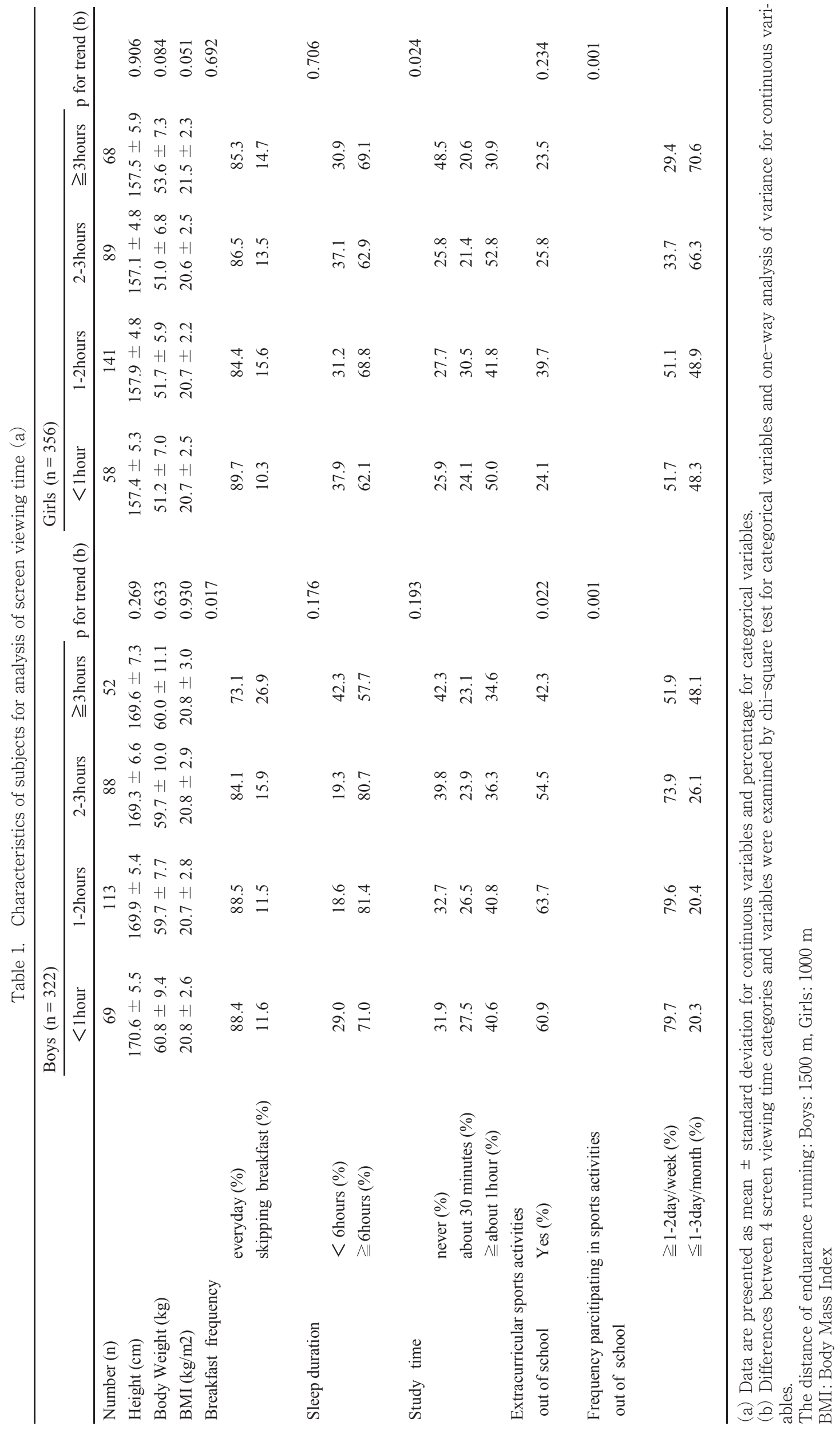


Table 2. Association of screen-time viewing with grip strength, standing broad jump distance and endurance running speed ( $\mathrm{n}=678)(\mathrm{a})$.

\begin{tabular}{|c|c|c|c|c|c|c|}
\hline $\begin{array}{l}\text { Boys } \\
\mathrm{n}=322\end{array}$ & $\begin{array}{c}\text { Screen viewing } \\
\text { time }\end{array}$ & $\begin{array}{c}<1 \text { hour } \\
n=69\end{array}$ & $\begin{array}{c}\text { 1-2hours } \\
\mathrm{n}=113\end{array}$ & $\begin{array}{c}\begin{array}{c}2-3 \text { hours } \\
n=88\end{array} \\
\end{array}$ & $\begin{array}{c}\geqq 3 \text { hours } \\
n=52\end{array}$ & $\begin{array}{l}\mathrm{p} \text { for trend } \\
\text { (b) }\end{array}$ \\
\hline GS & Crude & $40.8(39.2-42.4)$ & $39.7(38.5-40.9)$ & $39.1(37.7-40.5)$ & $38.8(37.0-40.6)$ & 0.078 \\
\hline \multirow[t]{2}{*}{$(\mathrm{kg})$} & Model 1 (c) & $40.8(39.3-42.3)$ & $39.7(38.6-40.9)$ & $39.0(37.7-40.3)$ & $38.9(37.1-40.6)$ & 0.069 \\
\hline & Model 2 (d) & $40.5(39.1-42.0)$ & $39.5(38.3-40.6)$ & $39.0(37.8-40.3)$ & $39.7(38.0-41.4)$ & 0.421 \\
\hline SBJD & Crude & $240(235-245)$ & $235(231-239)$ & $232(228-237)$ & $226(220-232)$ & $<0.001$ \\
\hline \multirow[t]{2}{*}{$(\mathrm{cm})$} & Model 1 (c) & $240(235-245)$ & $235(231-239)$ & $232(227-236)$ & $227(221-233)$ & 0.001 \\
\hline & Model 2 (d) & $240(235-245)$ & $234(230-238)$ & $232(227-236)$ & $229(222-235)$ & 0.007 \\
\hline ERS & Crude & $4.46(4.32-4.59)$ & $4.26(4.15-4.36)$ & $4.12(4.01-4.24)$ & $3.84(3.69-3.99)$ & $<0.001$ \\
\hline \multirow[t]{2}{*}{$(\mathrm{m} / \mathrm{sec})$} & Model 1 (c) & $4.46(4.33-4.58)$ & $4.25(4.15-4.35)$ & $4.12(4.01-4.23)$ & $3.86(3.71-4.00)$ & $<0.001$ \\
\hline & Model 2 (d) & $4.42(4.31-4.53)$ & $4.20(4.12-4.29)$ & $4.13(4.04-4.22)$ & $3.99(3.86-4.12)$ & $<0.001$ \\
\hline Girls & Screen viewing & $<1$ hour & 1-2hours & 2-3hours & $\geqq 3$ hours & $\mathrm{p}$ for trend \\
\hline $\mathrm{n}=356$ & time & $\mathrm{n}=58$ & $\mathrm{n}=141$ & $\mathrm{n}=89$ & $\mathrm{n}=68$ & (b) \\
\hline GS & Crude & $27.4(26.1-28.7)$ & $26.5(25.6-27.3)$ & $25.4(24.4-26.4)$ & $25.1(24.0-26.3)$ & 0.005 \\
\hline \multirow[t]{2}{*}{$(\mathrm{kg})$} & Model 1 (c) & $27.4(26.2-28.7)$ & $26.5(25.7-27.3)$ & $25.5(24.5-26.5)$ & $24.8(23.7-26.0)$ & 0.001 \\
\hline & Model 2 (d) & $27.5(26.3-28.7)$ & $26.2(25.4-27.0)$ & $25.8(24.8-26.7)$ & $25.2(24.0-26.3)$ & 0.005 \\
\hline SBJD & Crude & $180(174-187)$ & $180(176-185)$ & $172(166-177)$ & $176(170-182)$ & 0.138 \\
\hline \multirow[t]{2}{*}{$(\mathrm{cm})$} & Model 1 (c) & $179(173-186)$ & $180(176-184)$ & $171(166-176)$ & $178(172-184)$ & 0.331 \\
\hline & Model 2 (d) & $180(174-186)$ & $178(174-182)$ & $173(168-177)$ & $180(175-186)$ & 0.759 \\
\hline ERS & Crude & $3.56(3.41-3.70)$ & $3.58(3.49-3.68)$ & $3.30(3.18-3.42)$ & $3.25(3.11-3.38)$ & $<0.001$ \\
\hline \multirow[t]{2}{*}{$(\mathrm{m} / \mathrm{sec})$} & Model 1 (c) & $3.54(3.40-3.68)$ & $3.58(3.49-3.67)$ & $3.28(3.17-3.40)$ & $3.29(3.16-3.43)$ & 0.001 \\
\hline & Model 2 (d) & $3.54(3.43-3.65)$ & $3.51(3.44-3.58)$ & $3.34(3.25-3.43)$ & $3.37(3.26-3.47)$ & 0.006 \\
\hline
\end{tabular}

(a) Data are means (95\% confidence interval).

(b) Analysis of variance.

(c) Adjusted for BMI (continuous variable), breakfast frequency (everyday, skipping breakfast), study time (never, about 30 minutes, $\geqq$ about 1 hour), sleep duration (<6hours, $\geqq 6$ hours).

(d) Additionally adjusted for frequency participating in sports activities out of school ( $\leqq 1-3$ day/month, $\geqq 1-2$ day/week) and extracurricular sports activities out of school (yes or no).

GS: grip strength, SBJD: standing broad jump distance, ERS: endurance running speed, Distance of endurance running:

Boys: $1500 \mathrm{~m}$, Girls: $1000 \mathrm{~m}$

BMI: Body Mass Index

いて検討した先行研究では，スクリーン時間と体幹筋と の関連を見た報告 ${ }^{9,35)}$ が 2 編あり，スクリーン時間と体 幹筋は，負の関連を認めることが報告されている。理由 として，スクリーン時間が長くなることで筋緊張拉よび 姿勢移動がそれぞれ減少する ${ }^{9}$ 負の要因が指摘されてい る。スクリーン時間と男子の握力で関連を認めなかった 理由は, 定かではないが, 握力は, 他の項目に比べ, 体 格との関係が高く，体格の発育に伴う筋力の増大が関係 していることが島田ら ${ }^{23)} に よ り$ 報告されており，これら の要因がスクリーン時間の負の影響を打ち消した可能性 が考えられる。

次に, 勉強時間と体力指標の関連については, 男子の 握力で勉强時間と有意な負の関連を認めた。 日本人高校 生に扮ける勉強時間と体力指標を検討した報告はないた め, 新しい知見を提示できたと思われる。 しかし, 男女 に执いて, 男子の握力以外の種目で勉強時間と有意な関 連を認めなかった，女子の握力と勉強時間に関連を認め なかった理由は, 不明である. しかし, 女子の握力 (Table
4, モデル 2 ）は, 有意性は認められないものの, 觔強時 間が長くなるにつれ, 負の傾向はみられている。また, 男女いずれも立幅跳拐よび持久走の走速度に関連を認め ない理由として, 自転車や徒歩などの身体活動を伴う通 塾の可能性があるかもしれない, 近年, 終業後, 塾等に

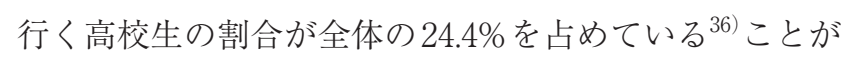
知られている，よって，塾等で勉強する時間は，運動以 外の身体活動時間を伴う可能性が考えられる。 さらに Esteban-Cornejoらは，6-18歳のスペイン人2038人の 男女を対象に, $20 \mathrm{mSR}$ の記録は学業成績（数学, 言語お よび評定平均值）と正の関連を認め，握力および立幅跳 の平均スコアは，学業成績との関連を認めないこと视を 横断的に検討している. Cooperらは, 宿題に費やす時間 と学業成績についてメ夕分析を行い，宿題に費やす時間 と学業成績は正の関連があると報告している ${ }^{13)}$ 。これら の報告から心肺体力は, 勉強時間の長さと正の関連があ る可能性も予想される. しかし, 本研究において, 男女 いずれも勉強時間と持久走の走速度に関連を認めないこ 


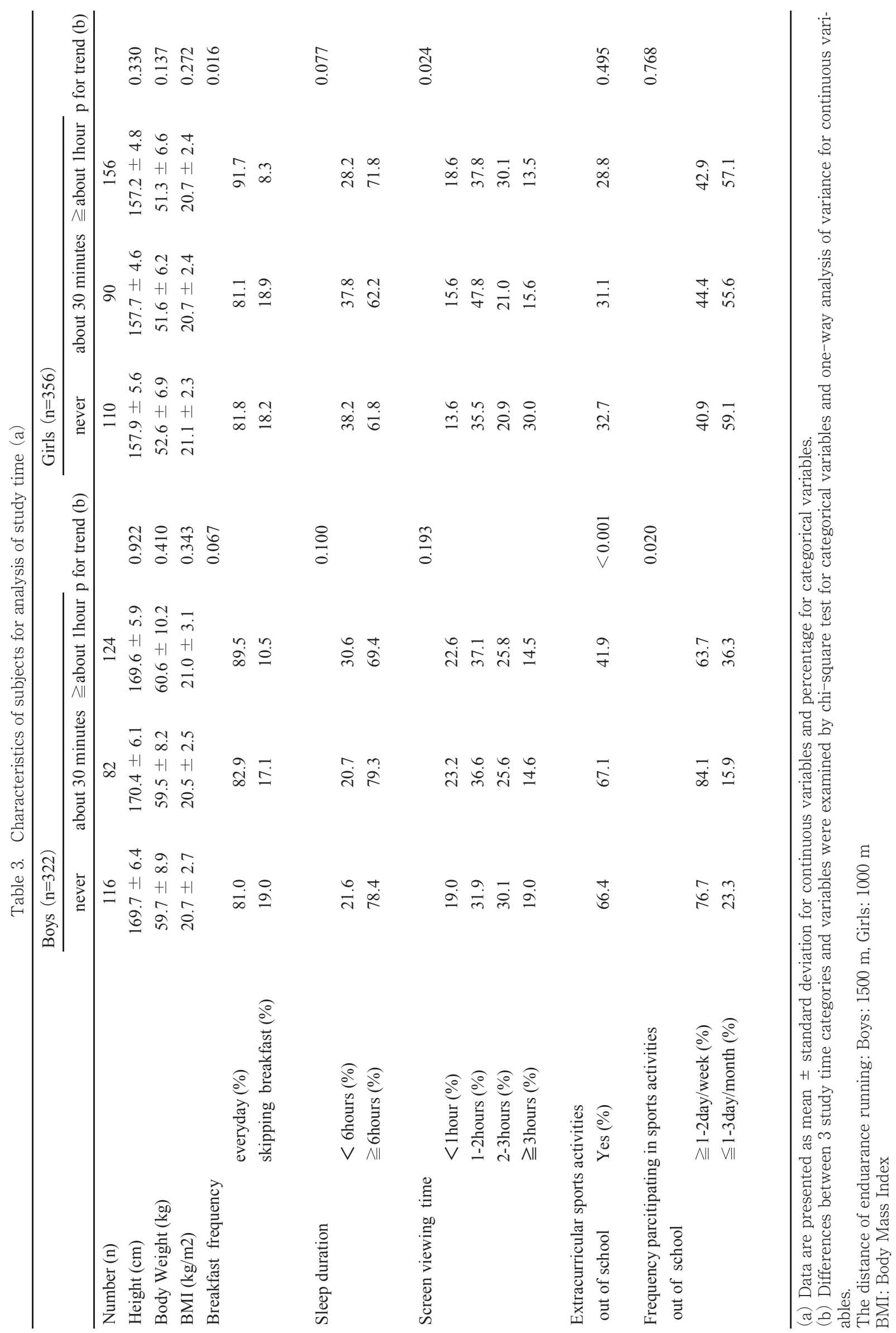


Table 4. Association of study time with grip strength, standing broad jump distance and endurance running speed $(\mathrm{n}=678)(\mathrm{a})$.

\begin{tabular}{|c|c|c|c|c|c|}
\hline $\begin{array}{l}\text { Boys } \\
\mathrm{n}=322\end{array}$ & Study time & $\begin{array}{l}\text { never } \\
\mathrm{n}=116\end{array}$ & $\begin{array}{l}\text { about } 30 \text { minutes } \\
\qquad \mathrm{n}=82\end{array}$ & $\begin{array}{l}\geqq \text { about 1hour } \\
n=124\end{array}$ & $\begin{array}{l}\mathrm{p} \text { for trend } \\
\text { (b) }\end{array}$ \\
\hline GS & Crude & $40.9(39.8-42.1)$ & $39.8(38.4-41.2)$ & $38.3(37.1-39.4)$ & 0.002 \\
\hline \multirow[t]{2}{*}{$(\mathrm{kg})$} & Model 1 (c) & $41.1(40.0-42.3)$ & $40.0(38.6-41.3)$ & $38.0(36.9-39.1)$ & $<0.001$ \\
\hline & Model 2 (d) & $40.8(39.7-41.9)$ & $39.5(38.2-40.8)$ & $38.6(37.5-39.7)$ & 0.007 \\
\hline SBJD & Crude & $235(231-239)$ & $238(233-243)$ & $230(226-234)$ & 0.075 \\
\hline \multirow[t]{2}{*}{ (cm) } & Model 1 (c) & $235(231-239)$ & $238(233-242)$ & $230(226-234)$ & 0.062 \\
\hline & Model 2 (d) & $235(231-239)$ & $237(232-241)$ & $231(227-235)$ & 0.190 \\
\hline \multirow{3}{*}{$\begin{array}{l}\text { ERS } \\
(\mathrm{m} / \mathrm{sec})\end{array}$} & Crude & $4.22(4.11-4.32)$ & $4.36(4.23-4.48)$ & $4.07(3.96-4.17)$ & 0.041 \\
\hline & Model 1 (c) & $4.24(4.15-4.34)$ & $4.33(4.22-4.45)$ & $4.06(3.96-4.15)$ & 0.006 \\
\hline & Model $2(\mathrm{~d})$ & $4.20(4.11-4.28)$ & $4.26(4.17-4.36)$ & $4.15(4.07-4.23)$ & 0.459 \\
\hline $\begin{array}{l}\text { Girls } \\
\mathrm{n}=356\end{array}$ & Study time & $\begin{array}{l}\text { never } \\
\mathrm{n}=110\end{array}$ & $\begin{array}{l}\text { about } 30 \text { minutes } \\
\qquad \mathrm{n}=90\end{array}$ & $\begin{array}{c}\geqq \text { about } 1 \text { hour } \\
n=156\end{array}$ & $\begin{array}{l}\mathrm{p} \text { for trend } \\
\text { (b) }\end{array}$ \\
\hline GS & Crude & $26.3(25.3-27.2)$ & $26.1(25.1-27.2)$ & $26.0(25.2-26.7)$ & 0.631 \\
\hline \multirow[t]{2}{*}{ (kg) } & Model 1 (c) & $26.4(25.5-27.3)$ & $26.1(25.1-27.1)$ & $25.9(25.1-26.7)$ & 0.432 \\
\hline & Model 2 (d) & $26.3(25.4-27.2)$ & $26.1(25.1-27.1)$ & $26.0(25.2-26.7)$ & 0.581 \\
\hline SBJD & Crude & $177(172-182)$ & $176(170-181)$ & $179(175-183)$ & 0.533 \\
\hline \multirow[t]{2}{*}{$(\mathrm{cm})$} & Model 1 (c) & $178(173-183)$ & $176(170-181)$ & $178(174-182)$ & 0.953 \\
\hline & Model 2 (d) & $177(173-182)$ & $175(171-180)$ & $179(175-182)$ & 0.660 \\
\hline \multirow{3}{*}{$\begin{array}{l}\text { ERS } \\
(\mathrm{m} / \mathrm{sec})\end{array}$} & Crude & $3.42(3.31-3.53)$ & $3.45(3.33-3.57)$ & $3.46(3.36-3.55)$ & 0.597 \\
\hline & Model 1 (c) & $3.46(3.35-3.56)$ & $3.44(3.32-3.55)$ & $3.44(3.35-3.52)$ & 0.746 \\
\hline & Model 2 (d) & $3.44(3.36-3.52)$ & $3.43(3.34-3.52)$ & $3.45(3.38-3.52)$ & 0.856 \\
\hline
\end{tabular}

(a) Data are means (95\% confidence interval)

(b) Analysis of variance.

(c) Adjusted for BMI (continuous variable), breakfast frequency (everyday, skipping breakfast), screen viewing time ( $<$ 1hour, $1-2$ hours, 2 -3hours, $\geqq 3$ hours), sleep duration ( $<6$ hours, $\geqq 6$ hours). (d) Additionally adjusted for frequency participating in sports activities out of school ( $\leqq 1-3$ day/ month, $\geqq 1-2$ day/week) and extracurricular sports activities out of school (yes or no).

GS: grip strength, SBJD: standing broad jump distance, ERS: endurance running speed, Distance of endurance running: Boys: $1500 \mathrm{~m}$, Girls: $1000 \mathrm{~m}$ BMI: Body Mass Index

とから，勉強時間が体力に与える負の要因のほか，学業 成績が体力指標に対し，潜在的な影響を与えている可能 性も示唆される。しかし, 今後詳細を調べる必要がある。

本研究の大きな特長として, BMI, 朝食摂取習慣などの 生活習慣, 体育授業以外の運動・スポーツ実施状況，運 動部活動の有無を含めた体力指標に影響を与える補正項 目を用い, 調整を図った点があげられる。一方で, 本研究 にはいくつかの限界がある。第一にスクリーン時間, 勉 強時間および体育授業以外の運動・スポーツ実施状況の 評価は, 自記式アンケートに基づいているため, 思い出 しバイアスおよび社会的に望ましい方向に回答が歪めら れる社会的望ましさのバイアス ${ }^{19,35)}$ があることは否めな い. 第二に対象者は, 同一高校かつ 2 年生のみの単学年 であり, 限定された集団であった。 よって, 今後は, 複数 校など大規模コホートをデザインし，検討を進めていく 必要があると考えられる。特に本研究の男子は, 運動部 活動に加入している者が比較的高く, 活動的な集団であ る可能性があり, 結果の一般化については, 慎重に検討
する必要がある。第三にスクリーン時間, 勉強時間, 睡眠 時間, 体育授業以外の運動・スポーツ実施状況は, 平日 か休日によって費やす時間が異なることが先行研究 ${ }^{37,38)}$ で示されている。しかしながら, 本研究では, それらを 平日と休日に分けて調査していない。平日と休日に分け たより詳細な検討が今後の課題といえる。第四に本研 究では学業成績を評価していないが, 学業成績が本研究 の結果に交絡している可能性は, 否定できない. 最後に, 本研究は横断研究であるため, スクリーン時間ならびに 勉強時間と体力の因果関係に関して言及できない.今後, 高校生を対象に縦断的な検討を含め, スクリーン時間な らびに勉強時間と体力指標のエビデンスを蓄積する必要 があると考えられる。

\section{結 論}

本研究は, 震災後における東北太平洋側地域の高校 2 年生を対象に自記式アンケート調査を用いてスクリーン 時間ならびに勉強時間と握力 (筋力), 立幅跳（瞬発力） 
および持久走の走速度（心肺体力）の関連を横断的に検 討した。 その結果，スクリーン時間ならびに勉強時間と 体力の関連において差異がみられた。すなわち, スクリー ン時間が長ければ体力は低い值を示す一方で, 勉強時間 が長ければ，ほほ体力と関連しないことが示された。

利益相反自己申告 : 申告すべきものはなし

\section{文献}

1）文部科学省. 子どもの体力向上のための総合的な方策に ついて (答申), 2002.

2) 村瀬浩二, 落合 優：子どもの遊びを取り巻く環境とそ の促進要因：世代間を比較して, 体育学研究, 52: 187200, 2007.

3）足立 稔, 酒向治子, 笹山健作： 3 年間にわたる子ども の体力縦断的変化が形態, 生活習慣, 心身の健康指標に 扣よぼす影響, 岡山大学大学院教育学研究科研究集録, 153: 81-87, 2013.

4）文部科学省. 平成 25 年度体力・運動能力調査結果の概 要及び報告書について, 体力・運動能力の年次推移の傾 向, 2014.

5) Ortega FB, Konstabel K, Pasquali E, Ruiz JR, HurtigWennlöf A, Mäestu J, Löf M, Harro J, Bellocco R, Labayen I, Veidebaum T, Sjöström M. Objectively measured physical activity and sedentary time during childhood, adolescence and young adulthood: a cohort study. PLoS One 8: e60871, 2013.

6) Eisenmann JC, Wickel EE, Welk GJ, Blair SN. Relationship between adolescent fitness and fatness and cardiovascular disease risk factors in adulthood: the Aerobics Center Longitudinal Study (ACLS). Am Heart J 149: 46-53, 2005.

7) Van Oort C, Jackowski SA, Eisenmann JC, Sherar LB, Bailey DA, Mirwald R, Baxter-Jones AD. Tracking of aerobic fitness from adolescence to mid-adulthood. Ann Hum Biol 40: 547-553, 2013.

8) Pate RR, Wang CY, Dowda M, Farrell SW, O'Neill JR. Cardiorespiratory fitness levels among US youth 12 to 19 years of age: findings from the 1999-2002 National Health and Nutrition Examination Survey. Arch Pediatr Adolesc Med 160: 1005-1012, 2006.

9) Grøntved A, Ried-Larsen M, Froberg K, Wedderkopp N, Brage S, Kristensen PL, Andersen LB, Møller NC. Screen time viewing behaviors and isometric trunk muscle strength in youth. Med Sci Sports Exerc 45: 1975-1980, 2013.

10）文部科学省. 高等学校教育の現状「 2 . 高校生の現状」, 30, 2014.

11）ベネッセ教育総合研究所. 第 2 回 放課後の生活時間調 査一子どもたちの時間の使い方, 2014.

12) Esteban-Cornejo I, Tejero-González CM, Martinez-Gomez D, del-Campo J, González-Galo A, Padilla-Moledo C, Sallis JF, Veiga OL; UP \& DOWN Study Group. Independent and combined influence of the components of physical fitness on academic performance in youth.
J Pediatr 165: 306-312, 2014.

13) Cooper H, Robinson JC, Patall EA. Does homework improve academic achievement? A synthesis of research, 1987-2003. Review of Educational Research 76: 1-62, 2006.

14）文部科学省. 新体力テスト実施要項 (12歳-19歳対象), 2000.

15) Ruiz JR, Castro-Piñero J, España-Romero V, Artero EG, Ortega FB, Cuenca MM, Jimenez-Pavón D, Chillón P, Girela-Rejón MJ, Mora J, Gutiérrez A, Suni J, Sjöström M, Castillo MJ. Field-based fitness assessment in young people: the ALPHA health-related fitness test battery for children and adolescents. $\mathrm{Br} J$ Sports Med 45: 518-524, 2011.

16) Someya Y, Kawai S, Kohmura Y, Aoki K, Daida H. Cardiorespiratory fitness and the incidence of type 2 diabetes: a cohort study of Japanese male athletes. BMC Public Health 14: 493, 2014.

17）アメリカスポーツ医学協会編（日本体力医学会体力科 学編集委員会監訳). 運動処方の指針一運動負荷試験と運 動プログラム-原著第 7 版, 南江堂, 東京, 66, 2006.

18) Ramsbottom R, Brewer J, Williams C. A progressive shuttle run test to estimate maximal oxygen uptake. Br J Sports Med 22: 141-144, 1988.

19）長野真弓, 足立 稔, 栫 ちか子, 熊谷秋三: 児童の体力な らびにスクリーンタイムと心理的ストレス反応との関 連性一地方都市郊外の公立㧍よび都市部私立小学校に 扔ける検討一, 体力科学, 64: 195-206, 2015.

20) Aires L, Mendonça D, Silva G, Gaya AR, Santos MP, Ribeiro JC, Mota J. A 3-year longitudinal analysis of changes in Body Mass Index. Int J Sports Med 31: 133-137, 2010.

21) Tanaka T, Nagata C, Oba S, Takatsuka N, Shimizu H. Prospective cohort study of body mass index in adolescence and death from stomach cancer in Japan. Cancer Sci 98: 1785-1789, 2007.

22) Yoshitake N, Okuda M, Sasaki S, Kunitsugu I, Hobara T. Validity of self-reported body mass index of Japanese children and adolescents. Pediatr Int 54: 397-401, 2012.

23）島田 茂, 出村慎一, 長澤吉則, 南 雅樹, 松澤甚三郎：継 続的運動実施頻度の差異が高専男子学生の体格および 体力に及ぼす影響: 3 年間の文部科学省の新体力テス 卜による縦断的資料を用いて, 日本生理人類学会誌, 11: 69-74, 2006.

24）高倉 実, 小林 稔, 宮城政也, 小橋川久光, 加藤種一：児 童に拄ける身体活動質問項目の信頼性と妥当性 - WHO Health Behaviour in School-aged Children Survey日本 語版の場合, 琉球大学教育学部紀要, 69: 199-205, 2006.

25）池本幸雄, 出村慎一, 長澤吉則, 山次俊介, 島田 茂, 南 雅 樹：高専男子学生の生活習慣㧍よび健康状態の特徵, 日 本生理人類学会誌, 8: 61-68, 2003.

26) Grassi GP, Turci M, Sforza C. Aerobic fitness and somatic growth in adolescents: a cross sectional investigation in a high school context. J Sports Med Phys Fitness 46: 412-418, 2006.

27) Cuenca-García M, Ruiz JR, Ortega FB, Labayen I, 
González-Gross M, Moreno LA, Gomez-Martinez S, Ciarapica D, Hallström L, Wästlund A, Molnar D, Gottrand F, Manios Y, Widhalm K, Kafatos A, De Henauw S, Sjöström M, Castillo MJ. Association of breakfast consumption with objectively measured and selfreported physical activity, sedentary time and physical fitness in European adolescents: the HELENA (Healthy Lifestyle in Europe by Nutrition in Adolescence) Study. Public Health Nutr 17: 2226-2236, 2014.

28) Dam TT, Ewing S, Ancoli-Israel S, Ensrud K, Redline S, Stone K; Osteoporotic Fractures in Men Research Group. Association between sleep and physical function in older men: the osteoporotic fractures in men sleep study. J Am Geriatr Soc 56: 1665-1673, 2008.

29) Pate RR, Dowda M, Ross JG. Associations between physical activity and physical fitness in American children. Am J Dis Child 144: 1123-1129, 1990.

30) Ara I, Vicente-Rodriguez G, Perez-Gomez J, JimenezRamirez J, Serrano-Sanchez JA, Dorado C, Calbet JA. Influence of extracurricular sport activities on body composition and physical fitness in boys: a 3-year longitudinal study. Int J Obes (Lond) 30: 1062-1071, 2006.

31) Hardy LL, Dobbins TA, Denney-Wilson EA, Okely $\mathrm{AD}$, Booth ML. Sedentariness, small-screen recreation, and fitness in youth. Am J Prev Med 36: 120-125, 2009 .
32) Suwa S, Tachibana K, Maesaka H, Tanaka T, Yokoya S. Longitudinal Standards for Height and Height Velocity for Japanese Children from Birth to Maturity. Clin Pediatr Endocrinol 1: 5-13, 1992.

33）宮本嘉巳, 中園嘉巳, 佐藤宣絨：持久性運動能力と心肺 機能の発達に及ぼす発育期柔道トレーニングの効果, 体 力科学, 34: 153-163, 1985.

34) Santos R, Mota J, Okely AD, Pratt M, Moreira C, Coelho-e-Silva MJ, Vale S, Sardinha LB. The independent associations of sedentary behaviour and physical activity on cardiorespiratory fitness. Br J Sports Med 48: 1508-1512, 2014.

35) Paalanne NP, Korpelainen RI, Taimela SP, Auvinen JP, Tammelin TH, Hietikko TM, Kaikkonen HS, Kaikkonen KM, Karppinen JI. Muscular fitness in relation to physical activity and television viewing among young adults. Med Sci Sports Exerc 41: 1997-2002, 2009.

36）厚生労働省. 平成 21 年度全国家庭児童調査結果の概要, 18歳未満の子供たちの状況, 14, 2009.

37）総務省統計局. 平成 23 年度社会生活基本調査, 2012.

38）石橋弘子, 高宮朋子, 井上 茂, 大谷由美子, 小田切優子, 北林蒔子, 下光輝一：某地方自治体公務員におけるテレ ビ視聴時間, 中高強度身体活動レベルと肥満の関連, 体 力科学, 61: 421-426, 2012. 